DOI: $\square$ https://doi.org/10.15407/techned2019.01.003

\title{
ON THE INHOMOGENEITY OF THE MAGNETIZATION OF CYLINDRICAL CORES IN THE UNIFORM MAGNETIC FIELD
}

Journal

Publisher

ISSN

Issue

Pages
Tekhnichna elektrodynamika

Institute of Electrodynamics National Academy of Science of Ukraine 1607-7970 (print), 2218-1903 (online)

No 1, 2019 (January/February)

$3-6$

\section{Author}

\section{K.V.Chunikhin}

Institute of Technical Problems of Magnetism National Academy of Sciences of Ukraine,

19, Industrialna st., Kharkiv, 61106, Ukraine,

e-mail: kvchunikhin@gmail.com

\section{Abstract}

The inhomogeneity of the magnetization of cylindrical cores of an electromagnet in a constant uniform external magnetic field is studied taking into account the nonlinearity of the magnetic properties of the material. The iterative algorithm for calculating resulting magnetic field inside a core, based on the numerical solution of the integral equation for the surface density of fictitious magnetic charges in conjunction with the approximated magnetization curve of a material, is proposed. The convergence of the iterative algorithm for arbitrary initial values of magnetic permeabi-lities is established. References 9 , figures 3 , table 1. 
Key words: magnetization, cylindrical core, magnetic field, integral equation, fictitious magnetic charge, magnetization curve.

Received: 05.03 .2018

Accepted: 10.08 .2018

Published: 10.01 .2019

\section{References}

1. Grinberg G.A. Selected questions of mathematical theory of electric and magnetic phenomena. Moskva-Leningrad: Izdatelstvo Akademii Nauk SSSR, 1948. 730 p. (Rus)

2. Kovalenko A.P. Magnetic control systems for space vehicles. Moskva: Mashinostroenie, 1975. 248 p. (Rus)

3. Mikhailov V.M. Calculation of electric and magnetic fields using integral and integrodifferential equations. Kiev: Uchebno-Metodicheskii Kompleks Vysshego Obrazovaniia, 1988. 60 p. (Rus)

4. Mikhailov V.M., Chunikhin K.V. On electrostatic analogy of magnetostatic field in inhomogeneous magnetized medium. Electrical engineering \& Electromechanics. 2017. No 5. Pp. 38-40. (Rus)

5. Mikhailov V.M., Chunikhin K.V. Testing of numerical solution of the problem of determining sources of magnetostatic field in magnetized medium. Electrical engineering \&

Electromechanics

2017. No 6. Pp. 42-46.

(Rus)

6. Rozenblat M.A. Demagnetization factors for high permeability rods. Zhurnal Tekhnicheskoi Fiziki . 1954. Vol. 24. No

4. Pp. 637-661. (Rus)

7. Tozoni O.V., Maergoyz I.D. Calculation of three-dimensional electromagnetic fields. Kyiv:

Tekhnika, 1974. 352 p. (Rus)

8. lanke E., Emde F., Lesh F. Special functions. Moskva: Nauka, 1977. 344 p. (Rus)

9. Jungerman J.A. Fourth-order uniform electric field form two charged rings. Review of Scientific Instruments.

1984. Vol. 55. No 9. Pp. 1479-1482. DOI: 
https://doi.org/10.1063/1.1137962

\section{PDF}

